\title{
EFFECT OF NPK AND SOME BIOFERTILIZERS ON GROWTH, YIELD AND QUALITY OF GARLIC PLANTS.
}

\author{
Wafaa A. Fekry \\ Plant Production Department, Efficient Productivity Institute, Zagazig \\ University, Egypt.
}

\section{ABSTRACT}

This study was conducted during the two successive winter seasons of 2004 /2005 and 2005/ 2006 at the Experimental Farm of Faculty of Agriculture ,Moshtohor, Benha University to investigate the effect of nitrogen, phosphorus and potassium fertilizers as well as rizobacterin and phosphorein biofertilizers on plant growth, chemical constituents, yield and its components, quality and storageability of garlic bulbs (Allium sativum L.) $c v$. Balady. The obtained results revealed that garlic cloves treated with rizobacterin and phosphorein as mixture or each of them separately in the presence of half recommended doses of chemical NPK fertilizers (60 kg N, $38 \mathrm{~kg} \mathrm{P}_{2} \mathrm{O}_{5}$ and $48 \mathrm{~kg} \mathrm{~K}_{2} \mathrm{O} / \mathrm{fed}$ ) significantly increased the studied characters compared to untreated plants in both seasons. However, the application of rizobacterin plus phosphorein combined with $60 \mathrm{~kg} \mathrm{~N}, 38 \mathrm{~kg} \mathrm{P}_{2} \mathrm{O}_{5}$ and $48 \mathrm{~kg} \mathrm{~K} \mathrm{~K}_{2} \mathrm{O} /$ fed gave the best results of growth parameters (plant height, numbers of leaves, fresh and dry weight per plant and bulbing ratio), plant minerals contents (N,P and K\%), bulb yield and its components (average bulb diameter, fresh weight, number of cloves per bulb, clove fresh weight and total as well as relative yield/ $f e d)$, moreover bulbs quality (N,P,K,TSS, total carbohydrates and volatile oils content) in both growing seasons. Fertilization of garlic with $120 \mathrm{~kg} \mathrm{~N}, 76 \mathrm{~kg} \mathrm{P}_{2} \mathrm{O}_{5}$ and $96 \mathrm{~kg} \mathrm{~K} \mathrm{~K}_{2} \mathrm{O} / \mathrm{fed}$ recorded maximum values of weight loss percentage in bulbs during storage in comparison with the treatment of rizobacterian and phosphorein mixture and/or every one separately in combination with 60 $\mathrm{kg} \mathrm{N}, 38 \mathrm{kgP}_{2} \mathrm{O}_{5}$ and $48 \mathrm{~kg} \mathrm{~K}_{2} \mathrm{O} / \mathrm{fed}$ which gave the lowest values in this respect.

Therefore, application of $60 \mathrm{~kg} \mathrm{~N}, 38 \mathrm{kgP}_{2} \mathrm{O}_{5}$ and $48 \mathrm{~kg} \mathrm{~K} \mathrm{~K}_{2} \mathrm{O} / \mathrm{fed}$ plus mixture of rizobacterin and posphorein could be recommended as the best treatment for raising garlic yield, improving bulb quality and to reduce the amounts of NPK fertilizers by $50 \%$ of the recommended dose.

Keywords: NPK, some biofertilizers, growth, yield \& quality, garlic plants. 


\section{INTRODUCTION}

Garlic(Allium sativum L.) is one of the most important vegetable bulb crop grown in Egypt. It is cultivated for local consumption as well as for exportation. It is commonly used as a spice and for medical purposes. Therefore, increasing garlic yield and improving bulb quality are main target for both growers and consumers. But usually it depends on many factors especially that influence of the plant growth. Application of nitrogen, phosphorus and potassium fertilizers either in a single or in a compound form enhance the growth and productivity of garlic plants.

In this respect, several researchers studied the promoting effect of NPK fertilizers on growth and chemical composition of garlic plants (Abou El-Magd and Abou El-Salehein, 1998; Bardisi et al., 2004 a ; El-Seifi et al., 2004; Mohamed, 2005 and Midan, 2007).

Furthermore, the importance of NPK fertilizers for bulb yield and its components, quality and storageability of bulbs were reported by Abou El-Magd and Abou El-Salhein, 1998; El-Zohery, 2003; Bardisi et al., 2004 b and ElMorsy and Shoker, 2005 on garlic and Rodriguez et al., 1999 and El-Shaikh, 2005 on onion

It has become essential to use untraditional fertilizers as substitutes or supplements for mineral fertilizer due to continous increase in the costs of chemical fertilizers and environmental pollution problems.Several investigators reported that using biofertilizers is considered a promoting alternative for chemical fertilizers by $\mathrm{N}_{2}$ - fixation and releasing certain nutrient elements $(\mathrm{P}, \mathrm{Fe}$, $\mathrm{Zn}, \mathrm{Mn}$ and $\mathrm{K}$ ) in addition to contributing with some phytohormones such as gibberellins and cytokinins (El- Haddad et al.,1993) and increasing the available phosphoruse in the soil by using phosphate solubilizing bacteria (phosphorein) (Midan, 2007). Treating garlic cloves with $\mathrm{N}_{2}$ - fixing bacteria of Azospirillum or Azotobacter and phosphate solubilizing bacteria either single or incombination promoted plant growth, yield and its components, chemical composition of plant and bulbs, as well as storability (Abou El-Khair, 2004; Bardisi et al, 2004 (a, b) and El- Seifi et al., 2004).

Therefore, this trail was conducted to study the effect of chemical NPK fertilizers levels and two biofertilizers (rizobacterin and phosphorein) as mixture or combined with the chemical fertilizers on growth, yield, chemical composition and storageability of garlic plants.

\section{MATERIALS AND METHODS}

Two field experiments were conducted at the Experimental Farm of Faculty of Agriculture Moshtoher, Benha University, Kalubia Governorate 
during 2004/ 2005 and 2005/ 2006 winter seasons ,to investigate the effect of mineral fertilizers N,P and $\mathrm{K}$ as well as the two biofertilizers rizobacterin and phosphorein on plant growth, chemical constituents, yield, bulb quality and storageability of garlic bulbs (Allium sativum L.) cv. Balady under clay loam soil conditions.

The physical and chemical analysis of the experimental soil in the two seasons are presented in Table 1.

Table 1: The physical and chemical properties of the experimental soil in 2004/2005 and 2005/2006 seasons.

\begin{tabular}{lcc}
\hline Soil property & $\mathbf{1}^{\text {st }}$ Season & $\mathbf{2}^{\text {nd }}$ Season \\
\hline Physical properties: & & \\
Sand (\%) & 16.97 & 17.50 \\
Silt (\%) & 35.10 & 34.98 \\
Clay (\%) & 43.66 & 41.52 \\
Texture class & Clay- loam & Clay- loam \\
Chemical properties: & & \\
pH & 7.5 & 7.6 \\
Organic matter $(\%)$ & 1.90 & 1.78 \\
Available N (ppm) & 82.70 & 82.45 \\
Available P $(\mathrm{ppm})$ & 20.50 & 21.00 \\
Available K(ppm) & 287.10 & 282.50 \\
\hline
\end{tabular}

Samples of the soil were obtained from $30 \mathrm{~cm}$ soil surface, and the analysis were performed according to methods described by Jackson (1970).

The experimental plots were arranged in a completely randomized block design with four replicates as follows:

1-Control( without anyapplications).

2-Rhizobacterin (Rhizo.) + phosphorein (Phos.).

3- $120 \mathrm{~kg} \mathrm{~N}+76 \mathrm{~kg} \mathrm{P}_{2} \mathrm{O}_{5}+96 \mathrm{~kg} \mathrm{~K} 2 \mathrm{O} /$ fed.(recommended doses of $\mathrm{N}, \mathrm{P}_{2} \mathrm{O}_{5}$ and $\mathrm{K}_{2} \mathrm{O} /$ fed.).

4-Rhizo. + $60 \mathrm{~kg} \mathrm{~N}+38 \mathrm{Kg} \mathrm{P}_{2} \mathrm{O}_{5}+48 \mathrm{~kg} \mathrm{~K} \mathrm{~K}_{2} \mathrm{O} / \mathrm{fed}$.

5- Phos. $+60 \mathrm{~kg} \mathrm{~N}+38 \mathrm{Kg} \mathrm{P}_{2} \mathrm{O}_{5}+48 \mathrm{~kg} \mathrm{~K} 2 \mathrm{O} /$ fed.

6-Rhizo. + phos.+ 60kg $\mathrm{P}_{2} \mathrm{O}_{5}+48 \mathrm{~kg} \mathrm{~K}_{2} \mathrm{O} /$ fed.

The experimental unit area was $11.2 \mathrm{~m}^{2}$. Each plot contained five ridges (4.0 $\mathrm{m}$ long and $70 \mathrm{~cm}$ width) four ridges were planted and one was left without planting as a guard one to avoid the movement of fertilizers from any plot to adjacent one.

The two biofertilizers used were rhizobacterin (contains live cells of efficient bacteria, 70\% Azotobacter and 30\% Azospirillum, as a source of nitrogen fixing bacteria) and phosphorein (contains Bacillus megatherium var 
phosophaticum, as a source of phosphate dissolving bacteria) each of the two biofertilizers was applied at the rate of $4 \mathrm{~kg} / \mathrm{fed}$. Both of them was taken from General Organization for Agriculture Equalization Foundation (GOAEF), Ministry of Agriculture, Egypt.

Garlic cloves were selected for uniformity in shape and size. Cloves were prepared by soaking in running water prior to sowing (6 hours) and treated with gum material then dipped for five minutes in thick paste of carrier based inoculants mixed with wet soft dust (1: 1: 5 ratio) i.e., rhizobacterin, phosphorein and soft dust, respectively.

Treated cloves were sown directly in the same day on both sides of ridges at distance of $7 \mathrm{~cm}$ apart. Planting was done on October $5^{\text {th }}$ and $7^{\text {th }}$,respectively in both seasons of study.

Nitrogen was applied in the form of ammonium nitrate $(33.5 \% \mathrm{~N})$, phosphorus was applied in the form of calcium superphosphate $\left(15-16 \% \mathrm{P}_{2} \mathrm{O}_{5}\right)$ and potassium was applied in the form of potassium sulphate $\left(48 \% \mathrm{~K}_{2} \mathrm{O}\right)$. The amounts of NPK fertilizers were added at three equal portions the first one was applied one month after planting, while the second and the third additions of fertilizers were added two and four months after planting, respectively. The normal agricultural practices of growing garlic plants were followed.

\section{Data recorded:}

\section{a- Plant growth measurements:}

A random sample of ten plants was taken from each plot at 135 days after sowing in both seasons of study to estimate plant height, number of leaves/plant, fresh and dry weight/ plant ( without roots ) as well as bulbing ratio.

$$
\text { Bullbing ratio }=\frac{\text { Nech diameter (cm) }}{\text { bub diametet (cm) }}
$$

As formulated by Mann(1952).

\section{b-Plant chemical composition:}

The dry matter of garlic plants ( foliage and bulbs) were finely ground and wet digested with sulfuric acid and perchloric acid (3:1). Total nitrogen, phosphorus and potassium contents were determined according to the methods described by Bremner and Mulvaney (1982), Olsen and Sommers (1982) and Jackson (1970), respectively.

\section{c-Yield and its components:}

At full maturity stage of bulbs ( 180 days from planting) plants of each experimental plot were harvested and left to be cured for 21 days, weighed (in $\mathrm{kg}$ ) and converted to record as total cured yield (ton / fed ) and relative yield (\%). A random sample of 10 bulbs was taken from each plot to determine the bulb 
fresh and dry weight $(\mathrm{g})$, average diameter $(\mathrm{cm})$, as well as number of colves/ bulb and colve fresh weight $(\mathrm{g})$.

\section{d-Bulb quality at harvesting time:}

A sample of $100 \mathrm{~g}$ of bulbs were oven dried at $70{ }^{\circ} \mathrm{C}$ till constant weight, ground and wet digested to determine total nitrogen, phosphorus and potassium contents according to the methods mentioned previously in plant chemical composition.

Total carbohydrates, total soluble solids (TSS) and volatile oils were determined according to Dubois et al. (1956), A. O.A.C. (1970)and Farag (1986), respectively as well as total protein by multiplying total nitrogen $\mathrm{x} 6.25$.

\section{e-Storageability of garlic bulbs:}

Samples of cured bulbs of uniform size ( $4 \mathrm{~kg}$ from every plot ) in both seasons were placed in nets and stored at room temperature $24{ }^{0} \mathrm{C}+5{ }^{\circ} \mathrm{C}$ with common storage conditions. In both seasons the storage zero time was April $20^{\text {th }}$ and the end was October $20^{\text {th }}$. Samples were weighted every month then the cumulative weight loss percentage was calculated.

\section{f-Statistical analysis:}

All the obtained data were subjected to statistical analysis according to Gomez and Gomez ( 1984). Means separation was done by using L.S.D. at 0.05 level of probability.

\section{RESULTS AND DISCUSSION}

\section{a. Plant growth measurements:}

Data presented in Table 2 revealed that inoculation of garlic cloves with mixture of the two biofertilizers rhizobacterin and phosphorein separately or combined with half of the recommended dose of chemical nitrogen, phosphorus and potassium fertilizers $\left(60 \mathrm{~kg} \mathrm{~N}, 38 \mathrm{~kg} \mathrm{P}_{2} \mathrm{O}_{5}\right.$ and $48 \mathrm{~kg} \mathrm{~K} \mathrm{~K}_{2} \mathrm{O} /$ fed) as well as application of NPK mineral fertilizers at full recommended doses (120 kg N, 76 $\mathrm{kg} \mathrm{P}_{2} \mathrm{O}_{5}$ and $96 \mathrm{~kg} \mathrm{~K} 2 \mathrm{O} / \mathrm{fed}$ ) significantly increased garlic plant growth over the control one. These results were true for all studied plant growth aspects; i.e., plant height, number of leaves/plant, fresh and dry weight/plant, as well as bulbing ratio. Moreover, the highest values of the above mentioned traits were obtained by the treatments $60 \mathrm{~kg} \mathrm{~N}, 38 \mathrm{~kg} \mathrm{P}_{2} \mathrm{O}_{5}$ and $48 \mathrm{~kg} \mathrm{~K}_{2} \mathrm{O} / \mathrm{fed}$ with rizobacterin and phosphorein as well as the other treatment $120 \mathrm{~kg} \mathrm{~N}, 76 \mathrm{~kg} \mathrm{P}_{2} \mathrm{O}_{5}$ and $96 \mathrm{~kg} \mathrm{k} \mathrm{k}_{2} \mathrm{O} /$ fed, respectively in both growing seasons of this trial. 
Such result could be explained by the effect of rhizobacterin ( which contains azotobacter and azospirillum bacteria ) in fixing the atmospheric nitrogen beside to the role of phosphorein which contains phosphate solubilizing bacteria in supplying the growing plants with available phosphorus ( Helda and Reynaldo, 1999) resulting in improving soil fertility and consequently plant development ,and due to releasing of certain other nutrients ; i.e., Fe, $\mathrm{Zn}$ and $\mathrm{Mn}$ ( Bhonde et al., 1997) through the break down of organic materials in the soil and make these elements in available forms. Furthermore, these bacteria have the ability to release some plant growth promoting substances, such as gibberellins, auxins and cytokinins which stimulate plant growth and dry matter accumulation ( Cacciari et al., 1989).

In this concern, the enhancing effect of NPK fertilization on plant growth may be due to the positive effects of these elements on activation of photosynthesis and metabolic processes of organic compounds in plants which in turn encourage the plant vegetative growth ( El-Morsy, 2004; El- Seifi et al., 2004 and Midan, 2007).

The positive interactions between the NPK mineral fertilizers and the two biofertilizers tested on plant vegetative growth may be due to the promoting effect of these minerals elements and biofertilizers together on the established plant roots and nutrient uptake (Bardisi et al., 2004 a)

These results are confirmed with those reported by Bardisi et al. (2004a) ; El-Seifi et al.(2004); El-Sayed et al.(2007) and Midan (2007) all on garlic and El-Shaikh (2005) on onion.

\section{b. Plant chemical composition:}

It is clear from the data in Table 3 that mineral NPK and biofertilizers treatments had significant effect on $\mathrm{N}, \mathrm{P}$ and $\mathrm{K}$ contents of garlic plants ( foliage and bulbs) compared to the control. Data illustrate also that NPK content of plant was positively affected with the application of the mixture of the two biofertilizers only or with NPK fertilizers during both seasons of this work. The maximum increments of macro-elements content was obtained from the both treatments; i.e., $60 \mathrm{~kg}, 38 \mathrm{~kg}_{2} \mathrm{O}_{5}$ and $48 \mathrm{~kg} \mathrm{~K}_{2} \mathrm{O} /$ fed plus the mixture of rizobacterrin and phosphrein or by the application of $120 \mathrm{~kg} \mathrm{~N}, 76 \mathrm{~kg} \mathrm{P}_{2} \mathrm{O}_{5}$ and $96 \mathrm{~kg} \mathrm{~K}_{2} \mathrm{O} /$ fed.

The favorable effect of biofertilizers on chemical constituents of garlic plants may be due to the fact that non- symbiotioc bacteria have the ability to supply the plants with $\mathrm{N}, \mathrm{P}$, and $\mathrm{K}$ and thereby increase chemical contents in different plant tissues (Bashan and Holguin, 1997 and Midan, 2007). 
Table 3: Effect of mineral NPK and biofertilizers (rizobacterin and phosphorein) on the mineral content of garlic plants (foliag and bulb) during $2004 / 2005\left(S_{1}\right)$ and $2005 / 2006\left(S_{2}\right)$ seasons.

\begin{tabular}{|c|c|c|c|c|c|c|}
\hline \multirow{3}{*}{$\begin{array}{l}\text { Characters } \\
\text { Treatments }\end{array}$} & \multicolumn{6}{|c|}{ Minerals content (\%) } \\
\hline & \multicolumn{2}{|c|}{$\mathbf{N}$} & \multicolumn{2}{|c|}{$\mathbf{P}$} & \multicolumn{2}{|c|}{$\mathbf{K}$} \\
\hline & $\mathbf{S}_{1}$ & $\mathbf{S}_{2}$ & $\mathbf{S}_{1}$ & $\mathbf{S}_{2}$ & $\mathbf{S}_{1}$ & $\mathbf{S}_{2}$ \\
\hline $\begin{array}{l}\text { Control } \\
120 \mathrm{~kg} \mathrm{~N}+76 \mathrm{~kg} \mathrm{P}_{2} \mathrm{O}_{5}+96 \mathrm{~kg}\end{array}$ & 2.05 & 2.00 & 0.292 & 0.284 & 1.27 & 1.21 \\
\hline $\mathrm{K}_{2} \mathrm{O} /$ fed & 2.88 & 2.65 & 0.410 & 0.398 & 1.87 & 1.83 \\
\hline Rizo. + Phos. & 2.25 & 2.20 & 0.324 & 0.310 & 1.42 & 1.37 \\
\hline $\begin{array}{l}\text { Rizo. } 60 \mathrm{~kg} \mathrm{~N}+38 \mathrm{~kg} \mathrm{P}_{2} \mathrm{O}_{5}+ \\
48 \mathrm{~kg} \mathrm{~K} \mathrm{~K}_{2} \mathrm{O} / \mathrm{fed}\end{array}$ & 2.73 & 2.60 & 0.380 & 0.365 & 1.61 & 1.65 \\
\hline $\begin{array}{l}\text { Phos. }+60 \mathrm{~kg} \mathrm{~N}+38 \mathrm{~kg} \mathrm{P}_{2} \mathrm{O}_{5} \\
+48 \mathrm{~kg} \mathrm{~K} \mathrm{O} / \mathrm{fed} \\
\text { Rizo. }+ \text { Phos. }+60 \mathrm{~kg} \mathrm{~N}+38\end{array}$ & 2.62 & 2.55 & 0.398 & 0.387 & 1.55 & 1.50 \\
\hline $\mathrm{kg} \mathrm{P}_{2} \mathrm{O}_{5}+48 \mathrm{~kg} \mathrm{~K} \mathrm{O} / \mathrm{fed}$ & 2.96 & 2.91 & 0.421 & 0.414 & 1.92 & 1.88 \\
\hline I.S.D. at 0.05 & 0.06 & 0.15 & 0.01 & 0.02 & 0.05 & 0.09 \\
\hline
\end{tabular}

Rizo. And Phos.: Rizobacterin and Phosphorein, respectively.

In this respect, such increments in the percentage of $\mathrm{N}, \mathrm{P}$ and $\mathrm{K}$ in garlic plants refers to NPK mineral fertilizers may be attributed to the increase in soil concentration of such macronutrients as a result of used these fertilizers in the root zoon which led to increasing the amounts absorbed by plant roots (ElZohery, 2003). These results are in conformity with those obtained by Abou ElMagd and Abou El- Salehein(1998), Bardisi et al., (2004), El- Seifi et al.(2004) and Midan (2007) all are working on garlic and El- Shaikh (2005) on onion.

\section{c. Yield and its components:}

Data presented in Table 4 reveal the effect of N,P and K fertilizers level, the two biofertilizers used (rizobacterin and phosphorein ) and their mixtures on bulb yield and its components for garlic plants.

Such data show that application of the two biofertilizers in combination only or with chemical fertilizers resulted in the heaviest yield of garlic bulbs and its components compared with the control. Moreover, application of rizobacterin and phosphorein plus $60 \mathrm{~kg} \mathrm{~N}, 38 \mathrm{~kg} \mathrm{P}_{2} \mathrm{O}_{5}$ and $48 \mathrm{~kg} \mathrm{~K} 2 \mathrm{O} /$ fed followed by the treatment $120 \mathrm{~kg} \mathrm{~N}, 76 \mathrm{~kg} \mathrm{P}_{2} \mathrm{O}_{5}$ and $96 \mathrm{~kg} \mathrm{~K} 2 \mathrm{O} / \mathrm{fed}$. gave the greatest values of total yield and its studied components; i.e., average bulb diameter, fresh and dry weight, number of cloves/bulb, clove fresh weight as well as total cured and relative yield. 
Obtained results were true during both seasons of this study. The increment in total cured yield over the control were $54 \%$ for rizobacterin and phosphorein plus $60 \mathrm{~kg} \mathrm{~N}, 38 \mathrm{~kg} \mathrm{P}_{2} \mathrm{O}_{5}$ and $48 \mathrm{~kg} \mathrm{~K}_{2} \mathrm{O} /$ fed in the first season and $66 \%$ in the second season, respectively.

The increase of total yield / fed might be due the increase of bulb weight and also this might be due to the favorable effect of interaction between mineral and biofertilizers on vegetative growth and dry matter accumulation (Table2) and plant contents of N, P and K (Table3).

In this concern the beneficial effects of biofertilizers ( rhizobacterin and phosphorein)on total yield and its components of garlic might be due to one or more from following mechanisms:

$\mathrm{N}$ - fixation, increasing available phosphate, production of plant growth promoting substances or organic acids, enhancing nutrient uptake or protection against plant pathogens (El-Haddad et al., 1993 ; Helda and Reynaldo, 1999).

The increment in total yield and its components due to the chemical fertilization may be refer to its positive effects on activation of photosynthesis and metabolic processes of organic compounds in plants which in turn encourage bulbs growth ( Groot et al., 2003). In this respect, both Abou El- Magd and Abou El- Salehein (1998) and Wange (1995) reported that the increase in bulb and clove weight and bulb diameter due to the modrate or increase level of NPK could result of increasing the dry matter in plant foliage, which is diverted to bulb felling also enhancing the photosynthesis. These results are in conformity with those reported by Bardisi et al., 2004 b; El-Morsy, 2005; Mohamed , 2005; ElSayed, 2007 and Midan , 2007 all working on garlic and El- Shaikh, 2005 on onion.

\section{d. Bulb quality:}

Results in Table 5 show that, mineral and biofertilizers were used had significant effect on N,P and K content, total protein, total carbohydrates, TSS and volatile oils contents in cloves. The highest values of these characters were obtained after inoculation with rizobacterin and phosphorein plus received $60 \mathrm{~kg}$ $\mathrm{N}, 38 \mathrm{~kg} \mathrm{P}_{2} \mathrm{O}_{5}$ and $48 \mathrm{~kg} \mathrm{~K}_{2} \mathrm{O} /$ fed and that was followed by the treatment 120 $\mathrm{kg} \mathrm{N}, 76 \mathrm{~kg} \mathrm{P}_{2} \mathrm{O}_{5}$ and $96 \mathrm{~kg} \mathrm{~K} 2 \mathrm{O} /$ fed. These results were true in both seasons of this work. The favorable effect of biofertilizers on chemical constituents of garlic cloves may be due to the fact that non- symbiotic bacteria (phosphorein) have the ability to supply the growing plants with $\mathrm{N}, \mathrm{P}$, certain micronutrients and phytohormones that could stimulate nutrients absorption and photosynthesis and thereby increase chemical contents in different plant tissues (Bashan and Holguin, 1997). Concerning the increment in garlic cloves minerals content due to NPK chemical fertilizers application might be owe to the vital role of these 
elements to enhance the photosynthetic activity, chlorophyll formation, accumulation of dry matter, N,P,K , total carbohydrates content in these tissues (Abou El-Magd and Abou El- Salehein, 1998) and volatile oils percentage in bulbs ( Abou El-Khair, 2004). These results are in agreement with those reported by El-Zohery (2003), Bardisi et al. (2004 b), El- Seifi et al.(2004), El -Morsy and Shokr (2005) and Mohamed (2005) on garlic. They found that cloves content of $\mathrm{N}, \mathrm{P}, \mathrm{K}$, protein, TSS, total carbohydrates and volatile oils were increased by increasing the elements $\mathrm{N}, \mathrm{P}$, and $\mathrm{K}$ through mineral or biofertilizers.

\section{e. Storageability:}

Data presented in Table 6 show clearly that all treatments in this trial tended to increase the weight loss from the first to the last month during storage period (180days). In this respect, fertilization of garlic plants with $120 \mathrm{Kg} \mathrm{N}, 76$ $\mathrm{kg} \mathrm{P}_{2} \mathrm{O}_{5}, 96 \mathrm{~kg} \mathrm{~K}_{2} \mathrm{O} /$ fed recorded maximum significant weight loss percentage, while the combined between the two biofertilizers used (rizobacterin and phosohorein) only gave the minimum weight loss percentage in bulbs compared with the control. The acceptable values in this concern may be achieved by the application of $60 \mathrm{~kg} \mathrm{~N}, 38 \mathrm{~kg} \mathrm{P}_{2} \mathrm{O}_{5}, 48 \mathrm{~kg} \mathrm{~K}_{2} \mathrm{O} /$ fed with rizobacterin and phosphorein. These results were true in both seasons of study.

These results may be due to the effect of interaction between mineral and biofertilizers on increasing the fresh weight (Table 4) and the high moisture levels in bulbs, consequently increased the weight loss through evaporation and dry matter loss through respiration (Abou El-Khair, 2004 ; Bardisi et al., 2004 b on garlic). In this concern, the reduction in weight loss was noticed in plants received the recommended P-dose in addition to the phosphate solublizing bacteria ( phosphorein), indicating the role of phosphorus in reducing water in bulbs and increasing dry matter (Midan,2007)

These results agree with those reported by Gomez and Munoz (1998), and El-Seifi et al. (2004) on garlic and Rodriguez et al. (1999) on onion.

Conclusively, it could be concluded from this study that fertilization of garlic plants with $60 \mathrm{~kg} \mathrm{~N}, 38 \mathrm{~kg}_{2} \mathrm{O}_{5}$ and $48 \mathrm{~kg} \mathrm{~K}_{2} \mathrm{O} /$ fed (half recommended dose) as mineral fertilizers combined with the two biofertilizers rizobacterin and phosphorein followed by the treatment $120 \mathrm{~kg} \mathrm{~N}, 76 \mathrm{~kg} \mathrm{P}_{2} \mathrm{O}_{5}$ and $96 \mathrm{~kg} \mathrm{~K}_{2} \mathrm{O} / \mathrm{fed}$ (the full recommended dose) under the same conditions of this trial, improved garlic morphological traits, chemical constituents, yield and its components as well as the quality of bulbs. Meanwhile, the best recorded values of weight loss percentage in bulbs during storage by the half recommended dose of chemical fertilizers combined with the two biofertilizers used. 


\section{REFFRENCES}

Abou El-Khair, E. E. (2004). Effect of irrigation and fertilization treatments on garlic crop and its storage ability under sandy soil conditions. Ph.D. Thesis, PP 158, Faculty Agriculture, Zagazig University, Egypt.

Abou El-Magd, M.M. and E.H. Abou El- Salehein (1998). Yield of bulbs, plant growth and chemical content of garlic as influenced by some fertilizing ratios. Egyptian. Journal of Applied Science, 13 (12): 141-156.

A.O.A.C. (1970). Official Methods of Analysis Agricultural Chemists, $11^{\text {th }}$ ed. published by the A.O.A.C., P.O. Boxi: 504 Washington.

Bardisi, A.; A.A.EL- Mansi; A.N. Fayed and E.E. Abou El-Khair (2004 a). Effect of mineral NP and biofertilizers on garlic under sandy soil conditions. 1- Growth and plant chemical composition. Zagazig Journal Agriculture Research, 31 (4A): 1425- 1440.

Bardisi, A.; A.A.EL- Mansi; A.N. Fayed and E.E. Abou El-Khair (2004 b). Effect of mineral NP and biofertilizers on garlic under sandy soil conditions. 2- Yield, bulb quality and storability. Zagazig Journal Agriculture Research., 31 (4A): 1441- 1462.

Bashan, Y. and G. Holguin (1997). Azospirillum- plant relationship. Environmental and physiological advances (1990-1996). Canadian. Journal Miocrobial, 43:103-121.

Bhonde, S.R.; S.B. Sharma and A.B. Chougule (1997). Effect of bio- fertilizer in combination with nitrogen through organic and inorganic sources on yield and quality of onion. National Hort. Research and Development Found., 17 (2): 1-3.

Bremner, J. M. and C.S. Mulvaney (1982). Total nitrogen. In: Page, A.L.; R.H. Miller and D. R. Keeney (Eds). Methods of Soil Analysis. Part 2, Journal Amer. Society Agron. Madison, W. I. USA, pp. 595-624.

Cacciari, D.L.; T. Pietrosanti and W. Pietrosanti (1989). Phytohormones like substances produced by single and mixed diazotrophic cultures of Azospirillum and Arthrobacter . Plant and Soil, 115: 151- 153.

Dubois, M.;K.A Gilles; J. Hamillon; P.A. Rebers and F.Smith (1956). Colorimetric methods for determination of sugars and related substances. Annual. Chemestry, 28:350.

El-Haddad, M.E;Y.Z. Ishanc and M.I. Mostafa(1993). The role of biofertilizers in reducing agricultures costs, decreasing environmental pollution and raising crop yields. Arab. Univ., Journal of Agriculture Science, 1 (1): 147-195. 
El-Morsy, A.H.A. (2004). Effect of some potassium levels and mepiquat choloride (PIX) on growth, yield and its quality of garlic (Allium sativum L.) Journal of Agriculture Science, Mansoura University, 29 (7): 41494158.

El-Morsy, A.H.A. and M.M. B.Shokr (2005). Effect of some nitrogen levels and bio- fertilizers on productivity of garlic and pea intrcropped. Journal of Agriculture Science, Mansoura University, 30 (4): 2183- 2199.

El-Sayed, hala A; Aida M.Abd EL- Rahim; E.I. EL-Gamily and E.E.M.Ismail (2007). Effect of fertilization and $\mathrm{GA}_{3}$ application on garlic (Allium sativum L.) growth, yield and it's components. Journal of Agriculture Science, Mansoura University, 32 (8): 6621- 6629.

El- Seifi, S.K; Sowsan M.H. Sarg; A.I.Abd El- Fattah and M.A. Mohamed (2004). Effect of biofertilizers and nitrogen levels on the productivity and quality of Chinese garlic under sandy soil conditions. Zagazig Journal of Agriculture Research, 31 (3): 889- 914.

El-Shaikh, K. A.A. (2005). Growth and yield of onion as affected by biofertilization, application of nitrogen and phosphorus fertilizers under south valley conditions. Assiut Journal of Agriculture Science, 36 (1): 37-50.

El-Zohery,S. S. M. (2003). Physiological studies on garlic crop. Ph.D. Thesis Zagazig University, Benha Branch, Faculty Agriculture, Moshtohor, pp160.

Farag, S.E.A.(1986). Studies of some marketable characters of irradiated garlic during storage Ph.D. Thesis, Ain Shams University, Faculty Agriculture, Cairo, Egypt.

Gomez, K.A. and A.A. Gomez (1984). Statistical Procedures for Agricultural Research. $2^{\text {nd }}$ ed., John Wiely and Sons, New York.

Gomez, R, and H,A, Munoz (1998). Biofertilization of garlic (Allium sativum L.) cultivar-Tropicales, 19 (2): 9- 13 (C.F. CAB International Abstracts).

Groot ,C.C.; L.F.M. Marcelis ; R. Boogaard; W.M. Kaiser and H. Lambers (2003). Interaction of nitrogen and phosphorus nutrition in determining growth. Plant and Soil, 248: 1-2.

Helda, R. and F. Reynaldo (1999). Phosphate solubilizing bacteria and their role in plant growth promotion. Biotechnology Advances, 17: 319-339.

Jackson, M. L. (1970). Soil chemical Analysis. Prentic Hall, Englewood Ceiffs, N. J.

Mann, L.K.(1952). Anatomy of garlic bulb and factors affecting bulb development. Hilgardia, 21: 195- 231, 
Midan, Sally A. (2007). Mineral phosphates, mycorrhizae and phosphate solubilizing bacteria relation to garlic plant behaviour. Journal of Agriculture Science, Mansoura University, 32 (4): 2725-2746.

Mohamed, A.A.W.A. (2005). Effect of fertilization and weed control on production and storageability of garlic. M.Sc. Thesis, Cairo University, Faculty of Agriculture, Egypt.

Olsen, S.R. and L.E. Sommers (1982). Phosphorous. In : Page, A.L.; R.H. Miller and D.R. Keeney (Eds). Methods of Soil Analysis. Part 2. Amer. Soc. Agron., Madison, W.I., USA. pp. 403-430.

Rodriguez, S.N.; N.C.Belmmer and A. Valenzuela (1999). Effect of nitrogen, phosphorus and potassium rates and forms upon onion (Allium cepa L.) bulb yield and quality. Agricultura Tecnica (Santiago) , 59 (2): 122 -132 (C.F. Hort . Abst., 70 (8) : 66 95).

Wange, S.S. (1995). Response of garlic to combined application of biofertilizers and nitrogen fertilizer. Journal of Soil and Crop, 5 (2): 115-116 (C.F.Hort. Abst., 66: 7657).

\section{تأثير الأسمدة النتروجينية ، الفوسفاتية ، البوتاسية وبعض الأسمدة

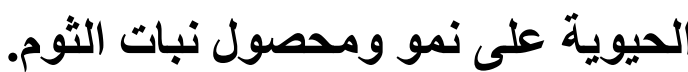

$$
\text { وفاء عادل فكرى }
$$

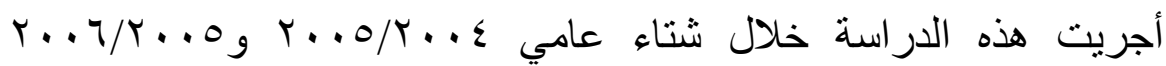

بمزرعة التجارب بكلية الزراعة بمشتهر جامعة بنها لدراسة تأثير كل من التسميد النتروجينى ، الفوسفاتي و البوتاسي الكيماوي وكل من الريزوباكترين و الفسفورين

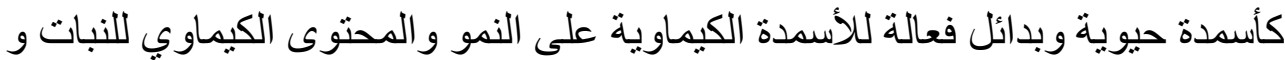

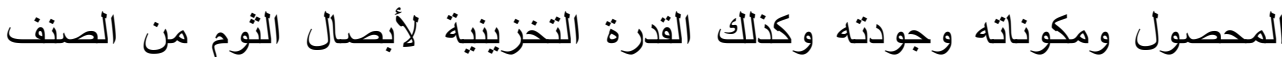
البلدي.

وقد أوضحت النتائج المتحصل عليها أن معاملة فصوص الثوم

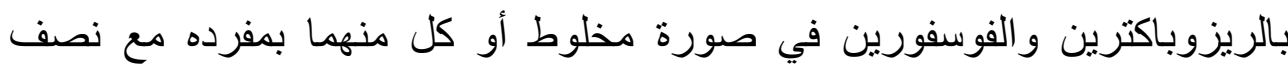

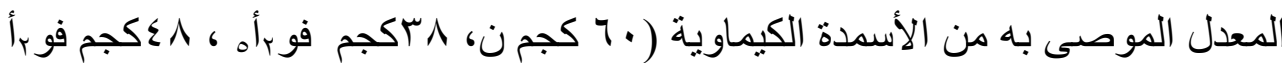


للفدان) أدت إلى زيادة معنوية لكل الصفات المدروسة مقارنة بالنباتات الغير معاملة

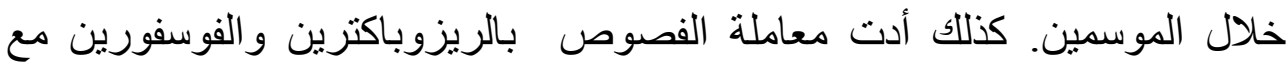

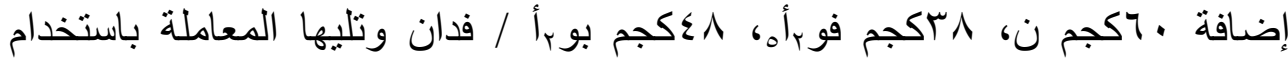

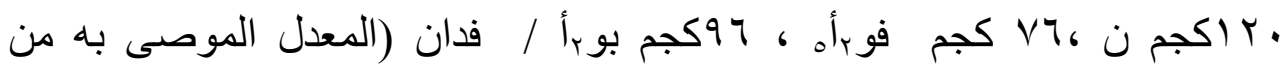

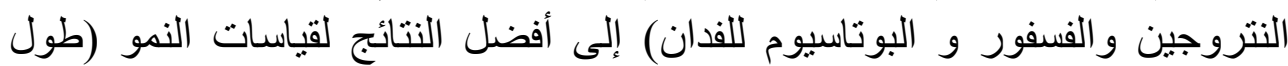
النبات ، عدد الأوراق ، الوزن الغض و الجاف ومعدل التبصيل )، المحتوى المعدني للنبات (النسبة المئوية للنتروجين ، الفوسفور و الوزن البوتاسيوم)، محصول الأبصال

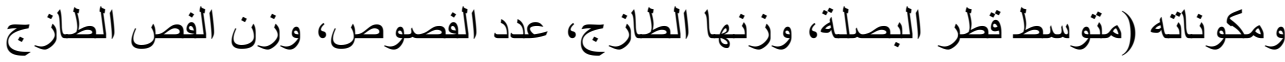
و المحصول الكلي والنسبي للفذان ) وكذلك جودة الأبصال (محتو اها من النتروجين،

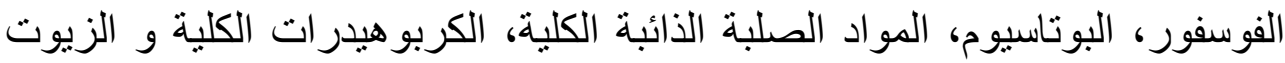

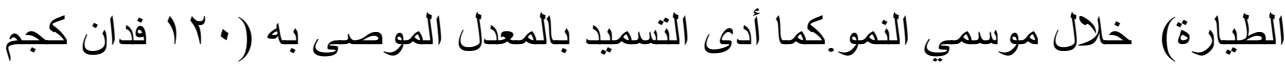

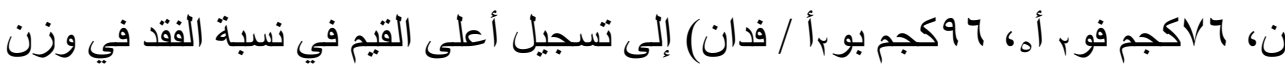

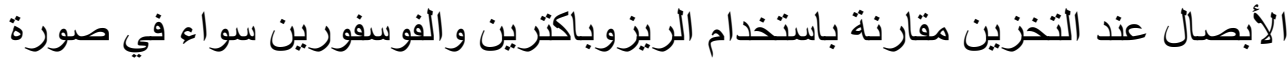

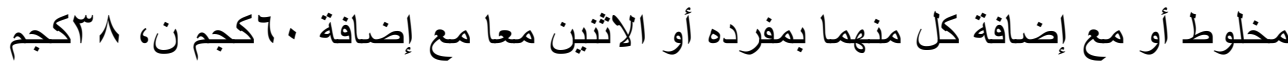

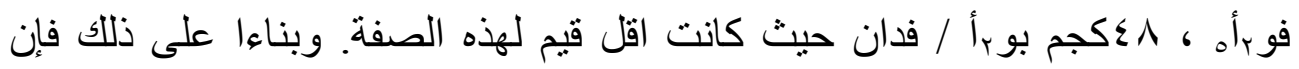
التوصية: أفضل معاملة يمكن أن يوصىى بها هي استخدام نصف كمية المعدل

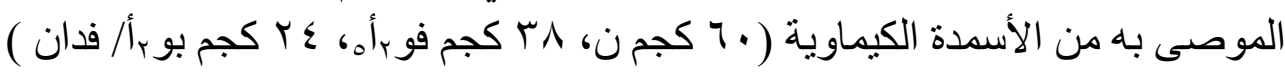
مع مخلوط من الريزوباكترين و الفوسفورين لزيادة محصول الثوم وتحسين جودة الأنية الأبصال. 